\title{
A simple model for the estimation of the number of fatalities due to floods in central Europe
}

\author{
M. Brazdova and J. Riha \\ Brno University of Technology, Institute of Water Structures, Brno, Czech Republic \\ Correspondence to: J. Riha (riha.j@fce.vutbr.cz)
}

Received: 18 April 2013 - Published in Nat. Hazards Earth Syst. Sci. Discuss.: 12 June 2013

Revised: 31 March 2014 - Accepted: 30 April 2014 - Published: 3 July 2014

\begin{abstract}
In this paper a model for the estimation of the number of potential fatalities is proposed based on data from 19 past floods in central Europe. First, the factors contributing to human losses during river floods are listed and assigned to the main risk factors: hazard - exposure - vulnerability. The order of significance of individual factors has been compiled by pairwise comparison based on experience with real flood events. A comparison with factors used in existing models for the estimation of fatalities during floods shows good agreement with the significant factors identified in this study. The most significant factors affecting the number of human losses in floods have been aggregated into three groups and subjected to correlation analysis. A close-fitting regression dependence is proposed for the estimation of loss of life and calibrated using data from selected real floods in central Europe. The application of the proposed model for the estimation of fatalities due to river floods is shown via a flood risk assessment for the locality of Krnov in the Czech Republic.
\end{abstract}

\section{Introduction}

The consequences of extreme flood events in central Europe that have occurred during the last decades show the necessity for a systematic approach to flood protection. Procedures based on the theory of risk management appear to be very effective for this purpose. One of the most important issues when implementing Directive 2007/60/EC of the European Parliament and of the Council of 23 October 2007 on the assessment and management of flood risks (Directive, 2007) is multi-criteria floodplain risk assessment.
Most of the existing flood risk studies in central Europe still focus on material losses and economic risk (Drab and Riha, 2010). One of the important risks which should be taken into account is loss of human lives. To include this risk component in analyses, it is necessary to estimate the potential loss of life (LOL) due to floods corresponding to a given return period.

In this paper a simple model is proposed for the estimation of the number of expected fatalities during a flood. Firstly, the factors contributing to the loss of life due to river floods were listed and analysed. The most significant factors contributing to the fatalities during past floods were aggregated to three groups and were included in the model for estimating the loss of life due to river floods. The model, which takes the form of a multiple regression function, was calibrated using highly reliable and detailed data from 19 selected real floods in central European countries like the Czech Republic, Slovakia, Poland, Austria, Germany, and Switzerland. The applicability of the model is restricted to similar countries with comparable flood forecasting and warning systems, flood routing techniques as well as living standards. The proposed model is demonstrated for the area of the town of Krnov in the Czech Republic, where flood protection measures have recently been proposed.

The objectives of the paper are to summarize factors contributing to the loss of life due to river floods and to propose a model for the estimation of the potential number of fatalities. The paper is structured as follows. In Sect. 2 a review and brief analysis of published models is carried out. The factors contributing to loss of human life during floods are listed and analysed in Sect. 3, which is the most comprehensive part of the text. In Sect. 4 a model for loss of life estimation is 
proposed based on empirical data from real floods. Section 5 is concerned with a case study. Conclusions and specifications for further research are found in Sect. 6.

\section{Current methods of modelling fatality numbers}

Since approximately the 1970s, studies dealing with the classification of the causes and circumstances of death due to flood action have been performed worldwide. The subject is the loss of life caused by river floods, dam break floods, and flooding caused by coastal events such as hurricanes, storm surges or typhoons. A comprehensive work identifying and analysing published methods for all types of floods was produced by Jonkman et al. (2008). The authors concluded that "coastal flood events are even more catastrophic than inland floods in terms of loss of life".

Human losses during river and coastal floods have been studied systematically by authors in the Netherlands, Great Britain, and the USA (e.g. Friedman, 1975; Lee et al., 1986; Waarts, 1992; Ramsbottom et al., 2003, 2004; Surendran et al., 2006; Priest et al., 2007; Vrouwenvelder and Steenhuis, 1997; Jonkman and Kelman, 2005; Jonkman, 2007, and Jonkman et al., 2008, 2009). In many cases the impacts of both river and coastal floods were studied together.

Most of the methods for loss of life estimation use empirical data from real flood events. According to the review of relevant literature, most authors use the term "flood mortality" (Jonkman, 2007) or "fatality rate" (Graham, 1999), which is defined as the number of fatalities divided by the number of people exposed, or the population at risk (PAR). Individual authors express mortality using various factors that influence the loss of life caused by a given flood type.

Waarts (1992) used data collected regarding the catastrophic coastal flood which affected the southwest of the Netherlands in February 1953. Aside from enormous economic losses the flood also brought 1835 fatalities. Waarts (1992) classified the area in which flooding resulted in fatalities into three zones, namely regions with high flow velocity, regions with rapidly rising water levels, and remaining zones. He derived an exponential function where water depth was the only factor. Formulas which were formally the same were proposed by Japanese author Mizutani (1985; quoted in Tachi personal communication, cited in Jonkman et al., 2008) for typhoons Isewan and Jane. Based on Waarts' formula, Vrouwenvelder and Steenhuis (1997) expressed flood mortality as a function of water depth and the rate of water level rise. The formulas proposed suffer due to not including important factors like warning, evacuation, and rescue activities in their analysis.

Vrouwenvelder and Steenhuis (1997) proposed a method taking into account the effect of collapsed buildings, the effect of distance from the dam breach, evacuation and other factors.
In his Ph.D. thesis (Jonkman, 2007) and in the following paper (Jonkman et al., 2008), Jonkman gives a comprehensive overview of approaches to loss of life modelling. The model proposed in his study is applicable both for coastal and river floods and includes factors such as water depth and velocity, rate of water level rise and the effects of evacuation and rescue of exposed people.

A promising method was proposed by Zhai et al. (2006), who derived a functional relationship between the number of flooded houses and the number of fatalities. This approach reflects mainly the population at risk and flood characteristics (depth, velocity, rate of water level rise) but omits the influence of other factors like warning, evacuation, etc. Because of this, there is considerable variation in the results obtained by the model.

In the UK, at the Department for Environment, Food and Rural Affairs (DEFRA) and at the Environment Agency, Flood and Coastal Defence R\&D Programme, a method for the estimation of the risk of loss of life during floods has been proposed (Ramsbottom et al., 2003, 2004). The project consisted of two phases. In the first phase, the Risks to People Methodology was developed. The procedure is based on an assessment of three factors: flood hazard, human vulnerability and area vulnerability. For the flood hazard rating the results of human instability testing were used (Abt et al., 1989). Three case studies for areas in the UK demonstrated good agreement between modelling results and historical data. The second phase involved the development of guidelines that explain how the method can be applied in flood risk management, urban planning and relevant flood protection activities.

The previously mentioned project was the basis for research conducted by Priest (2007), who used data regarding historical flood events in Europe. The applicability of models proposed by Ramsbottom et al. (2003, 2004) for flood management in central Europe was assessed as part of the project. Priest (2007) proposed an improved model which should be flexible enough to be widely applied both on a regional and national level.

The impact of dam break floods was studied by Brown and Graham (1988), DeKay and McClelland (1993) and Graham (1999). Brown and Graham (1988) compiled a formula for the estimation of potential fatalities due to dam failure. The PAR and available warning/evacuation time are factors taken into account. DeKay and McClelland (1993) derived models distinguishing floods with low and high hazard potential. PAR and available evacuation time are the relevant factors used in the model. Graham (1999) expresses the loss of life (LOL) as a percentage of PAR loss depending on the flood hazard, warning time and the response to the warning. The latter factor reflects the preparedness of society against flood risk.

In the case of relatively shallow water, mortality is expressed based on tests investigating the stability of people in flowing water. The aim of such studies is to indicate factors influencing the stability of people in flowing water and to 
assign stability limits. One of the first such tests was carried out at Colorado State University (Abt et al., 1989). Tests were performed using both living bodies and rigid body monoliths similar in stature to humans. The research resulted in a critical product of velocity and water depth (sometimes called "flood intensity") related to the mass and length of people.

The stability of people in flowing water was also assessed within a project (RESCDAM, 2000) conducted under the supervision of the Finnish Environment Institute in Helsinki. The aim was to identify the limits of individual factors contributing to loss of stability and compile guidelines for rescue activities in the case of dam break floods. At the Czech Technical University in Prague similar research consisting of 725 tests was carried out by Salaj (2009), who studied the effect of factors like water depth and velocity, the weight and height of people, their gender, skills and type of clothing. The most important factors were water depth and velocity. The comparison of the experimental results of the aforementioned research projects shows that the resulting critical flood intensity obtained by Salaj (2009) fits the data of RESCDAM (2000) quite well, while the data set published by Abt et al. (1989) is to a certain degree different, providing higher stability of individuals. The reason is probably the different conditions present during testing and the varied characteristics of individuals moving in flowing water. Jonkman and Rowsell (2008) discuss how human instability relates to moment and friction instability. Lind and Hartford (2000) and Lind et al. (2004) present mechanical and empirical models of the hydrodynamics of moment instability (toppling) taking into account the height and weight of the exposed people, and the velocity and depth of the flowing water.

The review of existing models for loss of life estimation shows that they have been proposed and calibrated for conditions in different regions and for different types of floods (coastal and river floods, dam breaks, etc.). Experimental data from historical flood events are mostly used for the calibration of model parameters. Due to lack of data the existing models do not take into account all of the most relevant factors (Table 1), and in some cases factors are derived from expert judgement. The subjects of analysis are particularly large-scale flood events with extensive mortality like the coastal flood in 1953 in the Netherlands and the UK (Waarts, 1992; Kelman, 2003), Hurricane Katrina in 2005 (Jonkman et al., 2009), and other disastrous events in Asia. Experience shows that the number of fatalities in central European river floods is likely to differ significantly from the loss of life caused by other types of floods (coastal, dam break, etc.). Unfortunately, no relevant loss of life model has yet been proposed for inland river floods (similar to those in years 1997, 2002, 2006, 2008, and 2010) for the conditions present in central Europe. The objective of this paper is to propose a user-friendly model for estimating loss of life in conditions typical in the Czech Republic and surrounding central European countries.
Table 1 shows a summary of selected models developed for the estimation of human losses due to inland flooding. In the table the area of application, factors taken into account and method of data acquisition are mentioned for each model. The most commonly used factors are water depth and velocity, the rate of water level rise, warning and evacuation. The other remaining factors like preparedness, the collapse of buildings and vulnerability of individuals (weight, height, gender, clothing, etc.) are used less often.

\section{Factors contributing to human losses during river floods}

Models for loss of life estimation should take into account as much as possible the important factors contributing to fatalities during flood events. In this section the analysis of such factors is carried out in the following steps:

a. A comprehensive list of factors contributing to the loss of life due to river floods has been created (Table 2). They are referred to as "contributing factors" in the remainder of this paper. A more detailed description of contributing factors, their impact on loss of life and the availability of relevant data related to each factor has been assessed during research (Drbal et al., 2011); however, this information is not covered here due to its large extent.

b. The significance and importance of the contributing factors identified were assessed based on the analysis of fatality data from real flood events in central Europe. The Saaty method (Saaty, 2008) was used for the semiquantitative ranking of pairwise comparisons. The resulting "most important" contributing factors were compared with an overview of factors used by models developed for the estimation of loss of life (Table 1).

c. The most significant factors were identified and aggregated into three groups to reduce the number of parameters of the model proposed for the estimation of loss of life.

\subsection{Data from existing floods}

The first step was the collection of data from historical floods worldwide. The comprehensive records obtained from floods all around the world encompassed about 130 flood events. The data from past floods in which fatalities occurred have been used both for the identification of contributing factors and their sorting (Sect. 3.2), and for further calibration of the proposed model for the estimation of the number of fatalities during floods (Sect. 4). Of key importance in the assessment of the above-mentioned contributing factors was the availability, accuracy and reliability of relevant data describing 
Table 1. Overview of the selected models developed for the estimation of loss of life due to different kinds of floods.

\begin{tabular}{|c|c|c|c|c|c|c|c|c|c|}
\hline \multirow[t]{2}{*}{ Model } & \multirow{2}{*}{$\begin{array}{l}\text { Area of } \\
\text { application }\end{array}$} & \multicolumn{7}{|c|}{ Factors applied } & \multirow{2}{*}{$\begin{array}{l}\text { Data obtained from } \\
\text { HP-real floods } \\
\text { L-laboratory research }\end{array}$} \\
\hline & & 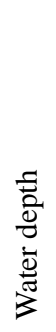 & 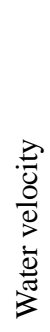 & 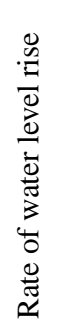 & 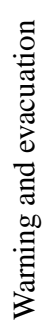 & 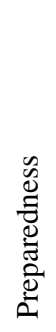 & 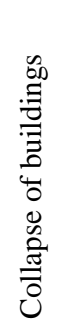 & 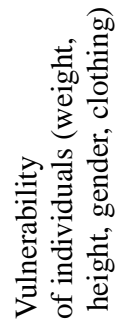 & \\
\hline $\begin{array}{l}\text { Waarts }(1992) \text { - detailed } \\
\text { Vrouwenvelder and Steenhuis (1997) } \\
\text { Jonkman }(2007,2008) \\
\text { Ramsbottom et al. (2003, 2004) } \\
\text { Priest (2007) }\end{array}$ & $\begin{array}{l}\text { River } \\
\text { and } \\
\text { coastal } \\
\text { floods }\end{array}$ & $\begin{array}{l}\bullet \\
\bullet \\
\bullet \\
\bullet \\
\bullet\end{array}$ & $\begin{array}{l}\bullet \\
\bullet \\
\bullet\end{array}$ & $\begin{array}{l}\bullet \\
\bullet \\
\bullet \\
\bullet \\
\bullet\end{array}$ & $\begin{array}{l}\bullet \\
\bullet \\
\bullet \\
\bullet \\
\bullet\end{array}$ & $\bullet$ & • & $\bullet$ & $\begin{array}{l}\text { HP } \\
\text { HP } \\
\text { HP/L } \\
\text { HP } \\
\text { HP }\end{array}$ \\
\hline $\begin{array}{l}\text { Brown and Graham (1988) } \\
\text { DeKay and McClelland (1993) } \\
\text { Graham (1999) }\end{array}$ & $\begin{array}{l}\text { Dam } \\
\text { break } \\
\text { floods }\end{array}$ & $\bullet$ & $\bullet$ & & $\begin{array}{l}\bullet \\
\bullet \\
\bullet\end{array}$ & $\bullet$ & & & $\begin{array}{l}\text { HP } \\
\text { HP } \\
\text { HP }\end{array}$ \\
\hline $\begin{array}{l}\text { Lind and Hartford (2000) } \\
\text { Abt et al. (1989) } \\
\text { Rescdam (2000) } \\
\text { Salaj (2009) }\end{array}$ & $\begin{array}{l}\text { Stability } \\
\text { of people } \\
\text { in flowing } \\
\text { water }\end{array}$ & $\begin{array}{l}\bullet \\
\bullet \\
\bullet \\
\bullet\end{array}$ & $\begin{array}{l}\bullet \\
\bullet \\
\bullet \\
\bullet\end{array}$ & & & & & $\begin{array}{l}\bullet \\
\bullet \\
\bullet\end{array}$ & $\begin{array}{l}\mathrm{HP} \\
\mathrm{L} \\
\mathrm{L} \\
\mathrm{L}\end{array}$ \\
\hline
\end{tabular}

such factors and enabling their quantification in cases involving both real flood situations and potential flood scenarios. The impact of each factor on loss of life had to be described and, if possible, also quantified.

During the investigation it was found that not all floods are described adequately; for some floods data regarding the reasons for fatalities were missing, contributing factors were not mentioned and, in some cases, the number of fatalities was not reliably identified. Further analysis also discovered dissimilarities between the conditions under which fatalities occurred. The most important factor was population density, which for example in Asian countries like China, Vietnam or Bangladesh is several times greater than that existing in the countries of central Europe. Incomparably bad preparedness and warning systems are the rule in such locations.

The comprehensive records obtained from floods all around the world that are cited in various sources encompass about 130 flood events. The data from past floods in which fatalities occurred have been used both for the identification of contributing factors and their sorting (Sect. 3.2), and for further calibration of the proposed model for the estimation of the number of fatalities during floods (Sect. 4). To ensure the homogeneity of the set of floods compiled for further statistical assessment only floods fulfilling the following criteria have been chosen from the entire set:
- The flood data must include real loss of life, material losses and information about the standard of living in the country and the flood routing procedures applied.

- The standard of living of selected countries must be comparable in terms of flood routing, flood mitigation and control, as well as land use and the value of property owned per capita. For this purpose the gross national product and the gross domestic product per capita were used. The gross domestic product per capita was expected to be higher than USD 30000 per capita.

- The population density in selected countries must be comparable with that of the Czech Republic and central Europe, that is between 100 and 400 inhabitants per $\mathrm{km}^{2}$.

For this reason, regions such as Asia, Africa and North America have been excluded from the analysis. The data from these regions concerning real floods were incomplete and unreliable. The living standards in most of the Asian and African countries involved are much lower than in central Europe. Also, preparedness, warning and rescue procedures are basically of a lower standard. The required complete data have been collected for 19 European floods, these being in the Czech Republic (1997, 1998, 2000, 2002, 2006, 2009 , two floods in 2010), Slovakia (1997, 1998, 1999), Austria (2002, 2005, 2009), Switzerland (2000, 2005, 2007), 
Table 2. Summary of contributing factors influencing loss of life during floods.

\begin{tabular}{|c|c|c|}
\hline $\begin{array}{l}\text { Risk } \\
\text { component }\end{array}$ & $\begin{array}{l}\text { Number of } \\
\text { the contributing } \\
\text { factor }\end{array}$ & $\begin{array}{l}\text { Contributing } \\
\text { factors }\end{array}$ \\
\hline \multirow[t]{9}{*}{ Hazard } & 1 & Flood extent \\
\hline & 2 & Speed of flood arrival \\
\hline & 3 & Rate of water level rise \\
\hline & 4 & Water depth \\
\hline & 5 & Water velocity \\
\hline & 6 & Water temperature \\
\hline & 7 & Water quality \\
\hline & 8 & Climate conditions \\
\hline & 9 & Floating debris \\
\hline \multirow[t]{8}{*}{ Exposure } & 10 & Preparedness of municipality \\
\hline & 11 & Hydrological forecast \\
\hline & 12 & Warning \\
\hline & 13 & Duration of flood \\
\hline & 14 & Response to warning \\
\hline & 15 & Time of day \\
\hline & 16 & Evacuation \\
\hline & 17 & Rescue activities \\
\hline \multirow[t]{11}{*}{ Vulnerability } & 18 & Weight of individuals \\
\hline & 19 & Height of individuals \\
\hline & 20 & Age of individuals \\
\hline & 21 & Gender \\
\hline & 22 & $\begin{array}{l}\text { Physical condition } \\
\text { of individuals }\end{array}$ \\
\hline & 23 & $\begin{array}{l}\text { Experience with } \\
\text { mobility in water }\end{array}$ \\
\hline & 24 & Clothing and footwear \\
\hline & 25 & Carrying of load \\
\hline & 26 & Use of support \\
\hline & 27 & Trapped in vehicle \\
\hline & 28 & Trapped in building \\
\hline
\end{tabular}

Germany (2002) and Poland (1997). Together with the references the data from these floods are summarized in Table 5. Incomplete data from other floods that did not fulfil the above-mentioned criteria have only been used as sources of information.

The material losses for the analysed floods have been converted to USD using exchange rates valid at the time the given flood took place. Inflation was taken into account by converting the flood losses to the average 2010 currency level, which was regarded as the reference level when constructing the model. For the conversion the gross domestic product deflator was used. The exchange rates were taken from the Czech National Bank pages (CNB), while the GDP deflators were sourced from data published by The World Bank (The World Bank).

Individual flood events have been described in more detail. The description includes the climatic and hydrological circumstances of the flood, the characteristics of the flooded area, a description of the course of the flood, material losses, the number of fatalities and their causes, and other information. Attention has been paid to the quantification of individual factors affecting the number of casualties and the aggregated factors (Sect. 3.3).

Finally, the classification of flood deaths proposed by Jonkman and Kelman (2005) has been adopted and completed by so-called "flood tourism", which occurs during practically every regional flood. Flood tourism includes different types of misconduct and wilful risk-taking behaviour. Crowds of people often gather on bridges and on the banks of swollen rivers to watch floods. Such onlookers can be swept away by the roaring waters; moreover, they complicate rescue and evacuation activities on the riverbanks. Frequently, recreational boaters attempt to boat or raft on flood waters, crashing, capsizing and drowning in the high velocity stream. Their irresponsible behaviour can sometimes also lead to the deaths of rescue personnel. The floods in the Czech Republic (1997, 2000, 2002, 2006, 2009, and 2010) have been classified according to the proposed distribution of causes of deaths and surrounding circumstances (Table 3). It must be noted that some data in Table 3 overlap, namely those from the flood in August 2002 in the Czech Republic mentioned both by Jonkman and Kelman (2005) (columns 3 and 4) and those discussed within this study (columns 5 and 6).

\subsection{List of contributing factors and their significance}

The list of factors influencing flood-induced fatalities was compiled based on experience from past floods in the Czech Republic as well as in neighbouring countries like Slovakia, Poland, Austria, Germany and Switzerland. The literature sources discussed in Sect. 2 were also taken into account. Identified contributing factors are listed in Table 2.

When employing the concepts of hazard, exposure and vulnerability as components of flood risk (Gouldby and Samuels, 2005; Drab and Riha, 2010), the contributing factors influencing the amount of loss of life during floods can be related to these components.

Factors expressing hazard (potential for injury, loss) like the extent of the flood, water depth, water velocity, rate of water level rise and speed of flood arrival can be determined using hydrological and hydraulic modelling. Increasing water depth, velocity, rate of water level rise and speed of flood arrival results in higher risk to the exposed population. Floating debris and ice can also be taken into account when modelling obstructive hydraulic structures like bridges, culverts or weirs. Floating debris is a source of hazard and can be assessed from the nature of the catchment (forestation, deposits on the floodplain). Unfavourable climate conditions and low water temperature during the flood complicate the mobility of people in water and rescue activities. Flooding and the washing out of pollutants from industrial facilities or waste water treatment plants located in the flooded area can cause a worsening in water quality. Experience shows that in the case of extreme floods, pollution concentrations are not 
Table 3. Causes and numbers of fatalities during selected floods.

\begin{tabular}{|c|c|c|c|c|c|}
\hline \multirow[t]{2}{*}{ Cause of death } & \multirow[t]{2}{*}{$\begin{array}{l}\text { Circumstances } \\
\text { of death }\end{array}$} & \multicolumn{2}{|c|}{$\begin{array}{c}\text { Europe, USA } \\
\text { (Jonkman and Kelman, 2005) }\end{array}$} & \multicolumn{2}{|c|}{$\begin{array}{c}\text { Czech Republic, floods in } 1997, \\
2000,2002,2006,2009,2010\end{array}$} \\
\hline & & Fatalities & Fatalities in $\%$ & Fatalities & Fatalities in $\%$ \\
\hline \multirow[t]{6}{*}{ Drowning } & As a pedestrian & 62 & 25.1 & 30 & 28.3 \\
\hline & Trapped in a vehicle & 81 & 32.8 & 5 & 4.7 \\
\hline & Falling from a boat & 7 & 2.8 & 3 & 2.8 \\
\hline & During a rescue attempt & 2 & 0.8 & 2 & 1.9 \\
\hline & In a building & 15 & 6.1 & 5 & 4.7 \\
\hline & Flood tourism & 0 & 0 & 4 & 3.8 \\
\hline \multirow[t]{6}{*}{ Physical trauma } & As a pedestrian & 4 & 1.6 & 1 & 0.9 \\
\hline & Trapped in a vehicle & 14 & 5.7 & 1 & 0.9 \\
\hline & On a boat & 2 & 0.8 & 0 & 0.0 \\
\hline & During a rescue attempt & 1 & 0.4 & 2 & 1.9 \\
\hline & In a building & 8 & 3.2 & 7 & 6.6 \\
\hline & Flood tourism & 0 & 0 & 1 & 0.9 \\
\hline Heart attack & & 14 & 5.7 & 8 & 7.5 \\
\hline Electrocution & & 7 & 2.8 & 0 & 0 \\
\hline $\mathrm{CO}$ poisoning & & 2 & 0.8 & 1 & 0.9 \\
\hline Fire & & 9 & 3.6 & 0 & 0 \\
\hline Other, or not known & & 19 & 7.7 & 36 & 35.8 \\
\hline Total & & 247 & 100.0 & 106 & 100.0 \\
\hline
\end{tabular}

usually high and have almost no influence on the number of lost lives.

Exposure as an act of being subjected to the influence of flooding is linked to contributing factors expressing contact between people and water, and its hazardous impact. Contributing factors like the general preparedness of inhabitants, timeliness and reliability of hydrological forecasting, warning and the response to warning can reduce the size of the exposed population. The duration of the flood usually does not directly influence loss of life; however, it may increase the stress on evacuated people. Well-organized evacuation and rescue activities can significantly reduce the number of lives lost, though on the other hand single fatalities have been reported during rescue attempts. A certain proportion of loss of life stems from unnecessary risk-taking behaviour, also including so-called "flood tourism" (Jonkman and Kelman, 2005). The percentage of flood-related deaths increases at twilight or during darkness, especially in the case of flash floods, when darkness can hinder warnings and rescue activities (DeKay and McClelland, 1993; McClelland and Bowles, 2002).

Vulnerability (susceptibility to injury, loss of life) is related to the characteristics and capabilities of individuals. The influence of factors like the weight, height, age, gender, physical conditions and experience with mobility in water of individuals, as well as the clothing and footwear worn, was studied via numerous stability tests (Abt et al., 1989; RESCDAM, 2000; Salaj, 2009). The vulnerability of individ- uals is also influenced by contributing factors like the carrying of loads and use of support when walking in flowing water. The trapping of people in vehicles was reported namely in the case of floods in the USA. Buildings can provide shelter to people against floating debris and the effect of moving water, and as such decrease the vulnerability of individuals, although in the event of destruction of the building by the flood, the hazard to the occupants will rise dramatically.

Some of the contributing factors, namely those related to vulnerability, are important when assessing fatality at the individual level. In further considerations these factors are averaged over the affected flooded area and the corresponding population at risk. Factors expressing local hazard (water depth, flow velocity, etc.) are projected into the aggregated parameters (e.g. parameter $D$ - see below) by integration over the flooded area.

It is evident that it is not practicable and feasible to take all contributing factors into account when proposing a model for the estimation of loss of life. Therefore, the aim of this study has been to find the factors with the most significant impact on the number of fatalities during flood events. The importance of the contributing factors identified was assessed using pairwise comparison based on the analysis of data and experience from past flood events. The pairwise comparison was carried out in two steps. First, qualitative analysis was applied to determine which criteria are more important. This was done by mutual comparison of the criteria via a "binary" rating in which the more important criteria were assigned the 
number " 1 " and the less important " 0 ". After that, each criterion was assigned a more apposite quantitative weight following a ranking scheme ranging from 1 to $5: 1$-equal preference, 2 -low preference, 3 -medium preference, 4 -high preference, and 5-dominant preference.

The definite assignment of weights was accomplished by the analysis of 35 questionnaires completed by professionals from the academic sphere (4), research institutes (3), engineering consultancies (5), river board agencies (7), administrative bodies (4), evacuation and rescue services and fire brigades (4), and other populations affected by floods (8). All respondents were provided with the classification of flood deaths summarized in Table 4 and with the detailed description of contributing factors contributing to flood fatalities. This enabled the assignment of factors listed in Table 2 to individual fatalities during floods and their causes and circumstances. The respondents filled in their own binary and "Saaty" (Saaty, 2008) scoring into the decision matrices which were afterwards subjected to final analysis and compiled in an ordered list of contributing factors according to the significance of their impact on loss of life.

The most important factors were compared with the factors used in existing models for loss of life estimation summarized in Table 1.

The resulting ranking of parameters based on the procedure mentioned above is shown in Table 4, where the contributing factors are ordered according to their final ranking. In this table the comparison with existing models for loss of life estimation is shown as well. Quite good agreement can be noted between the currently used factors and those identified by the formalized procedure in this study.

From the order of the factors shown in Table 4 it can be seen that the most important of them are the preparedness of the municipality, warning time, rescue activities, water depth, flood extent, water velocity, the speed of the flood's arrival, the response to the warning, evacuation and the rate of water level rise. Most of these factors are used in existing "loss of life" models.

The significance of the contributing factors shown in Table 4 closely fits findings reported in the literature, e.g. Jonkman and Kelman (2005), Jonkman et al. (2008). Flood extent, water depth and velocity, rate of water level rise and speed of flood arrival are the most cited factors related to flood hazard. Preparedness of the population at risk, warning, evacuation and rescue activities rank among the most important "exposure"-related factors. On the other hand, the relationship between factors related to the vulnerability of individuals (age, gender, height of individuals, etc.) and the number of fatalities cannot be reliably confirmed, which is partly due to the inadequacy of the records available.
Table 4. Overall assessment of contributing factor significance.

\begin{tabular}{|c|c|c|}
\hline $\begin{array}{l}\text { Contributing } \\
\text { factors }\end{array}$ & $\begin{array}{l}\text { Final } \\
\text { order } \\
\text { of } \\
\text { factors }\end{array}$ & $\begin{array}{l}\text { Factors taken } \\
\text { into account } \\
\text { in existing } \\
\text { models }\end{array}$ \\
\hline Preparedness of municipality & 1 & River floods \\
\hline Warning & 2 & River floods \\
\hline Rescue activities & 3 & \\
\hline Water depth & 4 & $\begin{array}{l}\text { River floods, } \\
\text { stability tests }\end{array}$ \\
\hline Flood extent & 5 & River floods \\
\hline Water velocity & 6 & $\begin{array}{l}\text { River floods, } \\
\text { stability tests }\end{array}$ \\
\hline Speed of flood arrival & 7 & \\
\hline Response to warning & 8 & \\
\hline Evacuation & 9 & River floods \\
\hline Rate of water level rise & 10 & River floods \\
\hline Physical condition of individuals & 11 & \\
\hline Floating debris & 12 & \\
\hline Time of day & 13 & \\
\hline Experience with mobility in water & 14 & \\
\hline Age of individuals & 15 & \\
\hline Duration of flood & 16 & \\
\hline Hydrological forecast & 17 & \\
\hline Climate conditions & 18 & \\
\hline Trapped in building & 19 & River floods \\
\hline Water temperature & 20 & \\
\hline Trapped in vehicle & 21 & \\
\hline Gender & 22 & Stability tests \\
\hline Weight of individuals & 23 & Stability tests \\
\hline Clothing and footwear & 24 & Stability tests \\
\hline Height of individuals & 25 & Stability tests \\
\hline Water quality & 26 & \\
\hline Carrying of load & 27 & \\
\hline Use of support & 28 & \\
\hline
\end{tabular}

\subsection{The aggregation of factors}

Due to the extent of the list of identified factors it is advisable to choose only the most important ones and aggregate them into a limited number of groups. The main intention was

- to take into account the most important factors influencing the number of fatalities (Table 4)

- to enable the evaluation of aggregated factors for past and potential future floods at locations subjected to flood risk analysis.

In our study, three groups (D, P, W) were proposed for further processing.

These groups do not include some contributing factors connected with vulnerability, floating debris, climatic conditions, water temperature and quality, and time of day. The reason for excluding these factors from further analysis is the lack of data concerning such circumstances gathered during 
Table 5. Data related to real flood events used for the calibration of the loss of life model.

\begin{tabular}{|c|c|c|c|c|c|c|}
\hline \multicolumn{2}{|c|}{ Flood event } & \multirow[t]{2}{*}{ Reference } & \multirow{2}{*}{$\begin{array}{l}\text { Number of } \\
\text { fatalities LOL }\end{array}$} & \multirow{2}{*}{$\begin{array}{l}\text { Material loss } D \\
\text { [USD] }\end{array}$} & \multirow[t]{2}{*}{$P$} & \multirow[t]{2}{*}{$W$} \\
\hline Date & Locality & & & & & \\
\hline 1997 - July & Czech Republic & WRI (1997) & 49 & $1.91 \times 10^{9}$ & -0.55 & -0.19 \\
\hline 1998 - July & Czech Republic & ERA $(20090$ & 10 & $6.18 \times 10^{7}$ & -0.43 & -0.53 \\
\hline 2000 - March & Czech Republic & ERA (2000) & 2 & $1.03 \times 10^{8}$ & 0.24 & 0.44 \\
\hline 2002 - August & Czech Republic & WRI (2002) & 17 & $2.32 \times 10^{9}$ & 0.14 & 0.11 \\
\hline 2006 - spring & Czech Republic & CHMI (2006) & 11 & $2.74 \times 10^{8}$ & 0.27 & 0.30 \\
\hline 2009 - June & Czech Republic & CHMI (2009) & 18 & $3.21 \times 10^{8}$ & 0.30 & -0.58 \\
\hline 2010 - May, June & Czech Republic & CHMI (2010a) & 3 & $2.45 \times 10^{8}$ & 0.36 & 0.47 \\
\hline 2010 - August & Czech Republic & CHMI (2010b) & 5 & $5.23 \times 10^{8}$ & 0.37 & -0.30 \\
\hline 1997 - July & Slovakia & MARD (1999) & 1 & $6.71 \times 10^{7}$ & -0.23 & 0.43 \\
\hline 1998 - July & Slovakia & MARD (1999) & 47 & $3.04 \times 10^{7}$ & -0.82 & -0.81 \\
\hline 1999 - July & Slovakia & MARD (1999) & 1 & $5.43 \times 10^{7}$ & 0.10 & -0.34 \\
\hline 2002 - August & Austria & Habersack and Moser (2003) & 9 & $2.27 \times 10^{9}$ & 0.30 & 0.23 \\
\hline 2005 - August & Austria & BLFUW (2006) & 3 & $1.40 \times 10^{7}$ & 0.53 & 0.48 \\
\hline 2009 - July & Austria & $\begin{array}{l}\text { Hübl et al. (2009), } \\
\text { Godina and Müller (2009) }\end{array}$ & 1 & $7.34 \times 10^{6}$ & 0.58 & -0.05 \\
\hline 2000 - October & Switzerland & Petrascheck and Hegg (2002) & 16 & $3.82 \times 10^{8}$ & -0.03 & 0.27 \\
\hline 2005 - August & Switzerland & BAFU (2008) & 6 & $2.33 \times 10^{9}$ & 0.38 & -0.26 \\
\hline 2007 - August & Switzerland & BAFU (2009) & 1 & $3.15 \times 10^{8}$ & 0.49 & -0.10 \\
\hline 1997 - July & Poland & WRI (1997, DKKV (2003) & 54 & $2.80 \times 10^{9}$ & -0.49 & -0.13 \\
\hline 2002 - August & Germany & DKKV (2003) & 21 & $8.75 \times 10^{9}$ & 0.26 & 0.05 \\
\hline
\end{tabular}

flood events, and in some cases their minor influence on loss of life.

Group $D$ is represented by material losses $D$. This group involves hazard factors contributing to material losses like the extent of the flood, water depth, water velocity and the duration of the flood and the number of people at risk (PAR). Extensive research carried out within project No. 129120 "Maintenance of flood prevention I" (MACR, 2006) based on census and GIS data (COSMC, 2009 and CSO, 2009) demonstrated close correlation between the PAR, property and property loss in the endangered area. The functional relationship between the number of flooded buildings and the number of fatalities was also confirmed by Zhai et al. (2006). Material losses $D$ were therefore used as an appropriate aggregated parameter containing all contributing factors mentioned above.

Group $P$ (general preparedness) expresses the general preparedness of society for flood management and control. It reflects flood awareness, the understanding of activities and behaviour during floods, etc. This is also related to the initiatives of flood committees, their response to hydrological forecasts and flood warnings and subsequent evacuation and rescue activities. Its value is determined by assessing the following items $P_{i}$ closely corresponding with general preparedness and the aforementioned contributing factors:

- $P_{1}$ - flood awareness and general knowledge about flood hazards
- $P_{2}-$ flood memory, frequency of flooding in the area of interest

- $P_{3}$ - existing flood documentation (flood extent maps, flood management plans)

- $P_{4}$ - understanding of activities and behaviour during floods

- $P_{5}-$ initiatives and activities of flood committees

- $P_{6}$ - response to hydrological forecast

- $P_{7}-$ response to flood warning

$-P_{8}-$ evacuation and rescue activities, level of training of personnel.

The items $P_{i}$ mentioned above are semi-quantitatively scored in the range of $\langle-1,1\rangle$. Some guidance for the scoring is given in Table 6. General "aggregated" preparedness $P$ (also in the range of $\langle-1,1\rangle)$ is determined using the formula

$P=\frac{1}{8} \cdot \sum_{i=1}^{8} P_{i}$,

where $P_{i}$ represents the scores of items mentioned above. Here -1 denotes a completely unsatisfactory state, +1 represents an excellent state. 
Table 6. Guidance on the scoring of general preparedness items $P_{i}$.

\begin{tabular}{|c|c|c|c|c|c|}
\hline \multirow[t]{2}{*}{$P_{i}$} & \multicolumn{5}{|c|}{ Score } \\
\hline & -1.0 & -0.5 & 0.0 & 0.5 & 1.0 \\
\hline$P_{1}$ & $\begin{array}{l}\text { No flood awareness or } \\
\text { knowledge about flood } \\
\text { hazard, sometimes ignorance }\end{array}$ & $\begin{array}{l}\text { Poor awareness, } \\
\text { underestimation } \\
\text { of flood hazard }\end{array}$ & $\begin{array}{l}\text { Common flood } \\
\text { awareness }\end{array}$ & $\begin{array}{l}\text { Fair knowledge about } \\
\text { flood hazards obtained } \\
\text { mostly from the media }\end{array}$ & $\begin{array}{l}\text { Excellent knowledge about } \\
\text { flood hazards via the media, } \\
\text { education, training, etc. }\end{array}$ \\
\hline$P_{2}$ & $\begin{array}{l}\text { Area never flooded, } \\
\text { no experience with } \\
\text { flooding }\end{array}$ & $\begin{array}{l}\text { Area flooded decades } \\
\text { ago, poor records } \\
\text { concerning flood losses }\end{array}$ & $\begin{array}{l}\text { Area flooded decades } \\
\text { ago, good records } \\
\text { concerning the risks }\end{array}$ & $\begin{array}{l}\text { Flooding still in } \\
\text { the memory of } \\
\text { the population }\end{array}$ & $\begin{array}{l}\text { Personal experience } \\
\text { with flooding }\end{array}$ \\
\hline$P_{3}$ & $\begin{array}{l}\text { Flood extent maps } \\
\text { or flood management } \\
\text { plans not available }\end{array}$ & $\begin{array}{l}\text { Existing flood } \\
\text { extent maps } \\
\text { are outdated }\end{array}$ & $\begin{array}{l}\text { Flood extent maps } \\
\text { drawn up based on } \\
\text { current hydrologic data, } \\
\text { but only poor flood } \\
\text { management plans exist }\end{array}$ & $\begin{array}{l}\text { Flood extent maps } \\
\text { drawn up, } \\
\text { flood management } \\
\text { and evacuation } \\
\text { plans available }\end{array}$ & $\begin{array}{l}\text { Flood extent maps drawn up, } \\
\text { updated digital versions of } \\
\text { flood management and } \\
\text { evacuation plans available }\end{array}$ \\
\hline$P_{4}$ & $\begin{array}{l}\text { Individuals have } \\
\text { no idea about } \\
\text { actions to take } \\
\text { during floods }\end{array}$ & $\begin{array}{l}\text { Limited (vague) } \\
\text { understanding of } \\
\text { what to do during } \\
\text { floods }\end{array}$ & $\begin{array}{l}\text { General understanding } \\
\text { of what to do before } \\
\text { and during a flood }\end{array}$ & $\begin{array}{l}\text { Quite good knowledge } \\
\text { of flood management } \\
\text { plans and corresponding } \\
\text { activities }\end{array}$ & $\begin{array}{l}\text { Perfect knowledge of flood } \\
\text { management plans and } \\
\text { understanding of what to do } \\
\text { in the event of flooding, } \\
\text { good preparedness }\end{array}$ \\
\hline$P_{5}$ & $\begin{array}{l}\text { No flood } \\
\text { committee } \\
\text { established }\end{array}$ & $\begin{array}{l}\text { Flood committee } \\
\text { established but } \\
\text { not trained, only } \\
\text { equipped with flood } \\
\text { fighting facilities }\end{array}$ & $\begin{array}{l}\text { Flood committee } \\
\text { established and generally } \\
\text { trained, poorly equipped } \\
\text { with flood-fighting } \\
\text { facilities }\end{array}$ & $\begin{array}{l}\text { Only moderately } \\
\text { experienced but } \\
\text { trained committee } \\
\text { with standard flood } \\
\text { fighting facilities }\end{array}$ & $\begin{array}{l}\text { Experienced and well- } \\
\text { trained flood committee } \\
\text { equipped with flood- } \\
\text { fighting facilities }\end{array}$ \\
\hline$P_{6}$ & $\begin{array}{l}\text { No response to } \\
\text { hydrological forecast, } \\
\text { no understanding } \\
\text { or belief }\end{array}$ & $\begin{array}{l}\text { Poor understanding } \\
\text { of hydrological } \\
\text { forecast and poor } \\
\text { response }\end{array}$ & $\begin{array}{l}\text { Approximate } \\
\text { understanding } \\
\text { of forecast and } \\
\text { adequate response }\end{array}$ & $\begin{array}{l}\text { Fair understanding } \\
\text { of hydrological } \\
\text { forecast and good } \\
\text { response }\end{array}$ & $\begin{array}{l}\text { Very good understanding } \\
\text { of hydrological forecast } \\
\text { and very good response }\end{array}$ \\
\hline$P_{7}$ & $\begin{array}{l}\text { No response } \\
\text { to warning, } \\
\text { no idea about } \\
\text { warning procedures } \\
\text { and response }\end{array}$ & $\begin{array}{l}\text { Only poor response } \\
\text { to warning, warning } \\
\text { system not trusted }\end{array}$ & $\begin{array}{l}\text { Adequate } \\
\text { response }\end{array}$ & $\begin{array}{l}\text { Good response } \\
\text { to warning }\end{array}$ & $\begin{array}{l}\text { Immediate and fast } \\
\text { response to warning }\end{array}$ \\
\hline$P_{8}$ & $\begin{array}{l}\text { Rescue system } \\
\text { does not exist, } \\
\text { no staff or } \\
\text { equipment } \\
\text { available }\end{array}$ & $\begin{array}{l}\text { Organized rescue } \\
\text { system does not exist, } \\
\text { volunteer basis, } \\
\text { no trained staff } \\
\text { available with randomly } \\
\text { acquired equipment }\end{array}$ & $\begin{array}{l}\text { Poorly organized but } \\
\text { functioning rescue system, } \\
\text { basic rescue equipment of } \\
\text { adequate quality }\end{array}$ & $\begin{array}{l}\text { Functioning rescue } \\
\text { system, trained staff } \\
\text { with equipment of fair } \\
\text { quality }\end{array}$ & $\begin{array}{l}\text { Efficiently functioning } \\
\text { rescue system, } \\
\text { well-trained, } \\
\text { experienced and well- } \\
\text { equipped personnel }\end{array}$ \\
\hline
\end{tabular}

Group $W$ (warning) includes factors influencing the warning of the population. The assessment is analogous to the case of group P. The contributing factors like the hydrological forecast, speed of the flood's arrival, warning and the rate of water level rise were included in the analysis. The following items $W_{i}$ have to be assessed:

- $W_{1}$ - hydrological forecast, its reliability, meteorological models used, etc.

- $W_{2}$ - speed of the flood's arrival, which significantly differs for upper and lower sub-catchments, for flash and regional floods

- $W_{3}$ - warning system, existence of digital warning systems

- $W_{4}$ - expected rate of water level rise.
These items are semi-quantitatively scored in the range of $\langle-1,1\rangle$ in a manner analogous to the case of group $\mathrm{P}$. Guidance on scoring is given in Table 7. The general "aggregated" effect of warning $W$ (in the range of $\langle-1,1\rangle$ ) is determined using the formula

$W=\frac{1}{4} \cdot \sum_{i=1}^{4} W_{i}$,

where $W_{i}$ represents the scores of items mentioned above.

Tables 6 and 7 give only general guidance for the scoring. In practical use the more detailed analysis of individual items has to be carried out; the local conditions in both groups $\mathrm{P}$ and $\mathrm{W}$ have to be taken into account. 
Table 7. Guidance for the scoring of warning items $W_{i}$.

\begin{tabular}{llllll}
\hline$W_{i}$ & \multicolumn{1}{c}{ Score } & & \\
\cline { 2 - 6 } & -1.0 & -0.5 & 0.0 & 0.5 & 1.0 \\
\hline$W_{1}$ & $\begin{array}{l}\text { No hydrologic forecast, } \\
\text { forecast not possible } \\
\text { (e.g. at small catchments) }\end{array}$ & $\begin{array}{l}\text { Only vague and } \\
\text { general forecast }\end{array}$ & $\begin{array}{l}\text { General forecast } \\
\text { for medium size } \\
\text { catchment }\end{array}$ & $\begin{array}{l}\text { Hydrologic forecast } \\
\text { provided in a standard } \\
\text { way by hydrologic } \\
\text { services }\end{array}$ & $\begin{array}{l}\text { Reliable hydrologic } \\
\text { forecast based on } \\
\text { contemporary technical } \\
\text { and modelling techniques }\end{array}$ \\
\hline$W_{2}$ & $\begin{array}{l}\text { Flood may arrive } \\
\text { within several } \\
\text { tens of minutes }\end{array}$ & $\begin{array}{l}\text { Flood arrives faster } \\
\text { than in 45 min }\end{array}$ & $\begin{array}{l}\text { Flood arrives } \\
\text { within several } \\
\text { hours }\end{array}$ & $\begin{array}{l}\text { Flood arrives } \\
\text { within 1 day }\end{array}$ & $\begin{array}{l}\text { Flood arrives within } \\
\text { several days }\end{array}$ \\
\hline$W_{3}$ & $\begin{array}{l}\text { Warning system } \\
\text { does not exist }\end{array}$ & $\begin{array}{l}\text { Poorly designed and } \\
\text { functioning } \\
\text { warning system }\end{array}$ & $\begin{array}{l}\text { Only moderately } \\
\text { reliable warning } \\
\text { system }\end{array}$ & $\begin{array}{l}\text { Fully functioning } \\
\text { traditional } \\
\text { warning system }\end{array}$ & $\begin{array}{l}\text { Sophisticated warning } \\
\text { system including digital } \\
\text { online alarm systems }\end{array}$ \\
\hline $\begin{array}{l}W_{4} \\
\text { Water rises at a rate of } \\
\text { several metres per hour } \\
\text { (floods in 1998, 2009) }\end{array}$ & $\begin{array}{l}\text { Water level rise about } \\
1 \text { m per hour (small } \\
\text { catchments in 2013) }\end{array}$ & $\begin{array}{l}\text { Rate of several } \\
\text { metres per day }\end{array}$ & $\begin{array}{l}\text { About 1 m per day } \\
\text { (floods in 1997, 2002) }\end{array}$ & $\begin{array}{l}\text { Water level rise } \\
\text { of several metres } \\
\text { over several days }\end{array}$ \\
\hline
\end{tabular}

\section{Fatality estimation model}

\subsection{General assumptions}

In order to calibrate the model, an extensive search was carried out for data regarding historical floods. As mentioned above, the first step involved the collection of data for floods occurring all over the world. The study showed that flood hazards and the preparedness of societies and their inhabitants vary extremely widely across the various continents and between individual countries, due to their different cultures, economies and living standards. Also, the required detailed data for evaluation were not available for the majority of floods. As a result, only 19 floods which took place in central European countries over the last approximately 15 years were chosen and used in the analysis. A list of these floods is shown in Table 5. The location and nature of the analysed floods limit the use of the proposed model to countries with similar climate, living standards and economies to Austria, the Czech Republic, Germany, Poland, Switzerland, the Slovak Republic, and other similar European countries.

As was mentioned above, the basic strategy was to deal exclusively with material losses, $D$. It was assumed that material losses reflect both the flood hazard (the destructive ability of the flood) and the number of endangered inhabitants (the amount of property in flooded areas corresponds to the size of the population at risk). In order to have practical applications this approach requires the use of techniques for loss estimation in selected flood scenarios. These methods are available in practically all countries in central Europe.

It is expected that the most important contributing factors (Table 4) are sufficient to express the number of fatalities during floods acceptably. They are aggregated into three groups, $\mathrm{D}, \mathrm{P}$, and $\mathrm{W}$, and expressed numerically by parameters (quantifiers) $D, P$, and $W$. Based on the available information and data, the material losses $D$ and number of fatalities LOL were assigned to 19 selected historical floods. The abovementioned scoring for parameters $P$ and $W$ was carried out for these floods (see Table 5).

\subsection{Functional dependence}

The functional dependence between "dependent" variable LOL and "independent" variables $D, P$, and $W$ was determined using correlation analysis. This dependence between LOL and $D, P$, and $W$ was searched for in such varied functional relationships as linear, exponential, logarithmic and power functions. It was discovered that the best fit approximation of loss of life is provided by the power function of variables $D, P$, and $W$. This can be proposed in a form which guarantees zero LOL for zero material losses and positive LOL for $P$ and $W$ within the range of $\langle-1,1\rangle$. The correlation coefficients expressed for individual pairs LOL- $D$, LOL$P$, LOL- $W$ after their linearization by logarithmization are as follows: $R_{\mathrm{LOL}, D}=0.544, R_{\mathrm{LOL}, P}=-0.595, R_{\mathrm{LOL}, W}=$ -0.372 .

Other dependencies gave much smaller correlation coefficients and in some cases did not satisfy logics requiring a positive number of fatalities for $D>0$.

\subsection{Model calibration and verification}

Based on the above-mentioned functional dependence analysis, the following general form was proposed for the model for the estimation of the number of human losses:

$y=k \cdot x_{1}^{b} \cdot x_{2}^{c} \cdot x_{3}^{d}$,

where $k, b, c, d$ are model parameters, $y$ is a "dependent" variable characterizing loss of life, and $x_{1}, x_{2}, x_{3}$ are 


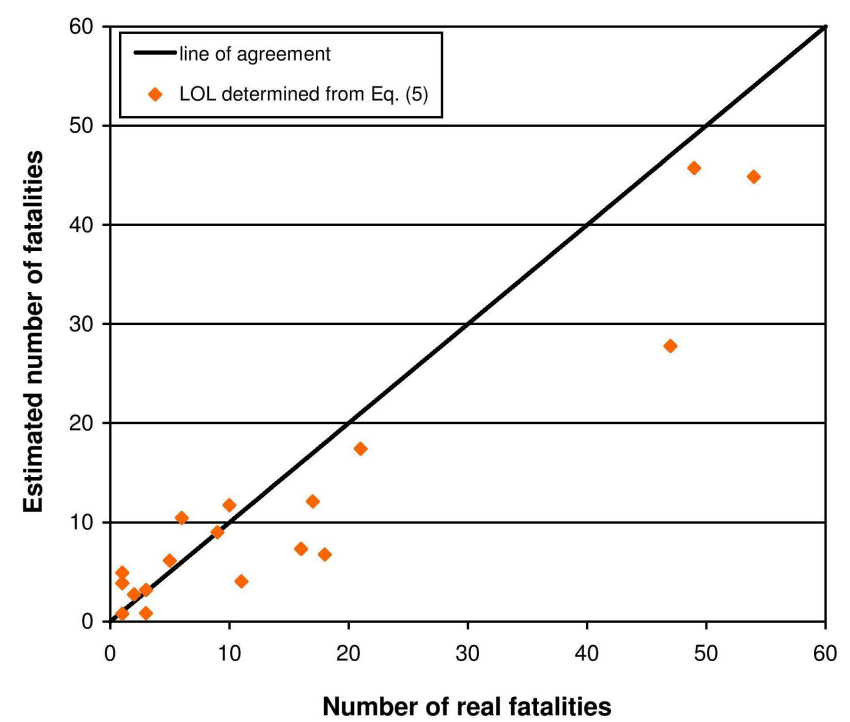

Figure 1. The degree of agreement between the real and calculated number of fatalities.

"independent" variables corresponding to material losses, preparedness and warning.

After substituting LOL for $y, 10^{a}$ for $k, D$ for $x_{1},(P+2)$ for $x_{2}$ and $(W+2)$ for $x_{3}$, Eq. (3) becomes

$\mathrm{LOL}=10^{a} \cdot D^{b} \cdot(P+2)^{c} \cdot(W+2)^{d}$.

For the optimization using the least square procedure the values of LOL, $D, P$, and $W$ were taken from Table 5 for the 19 selected floods. To determine parameters $a, b, c, d$ using the least square method, it is advantageous to logarithmize and so linearize Eq. (4). Therefore, in formula (4) the numeral "2" was added to parameters $P$ and $W$ to avoid logarithmization of negative values (parameters $P$ and $W$ vary within the interval of $\langle-1,1\rangle$ ).

When substituting the obtained parameters $a, b, c$, and $d$ into Eq. (4), after some manipulation the resulting formula for the estimation of loss of life was obtained:

$\mathrm{LOL}=0.075 \cdot D^{0.384} \cdot(P+2)^{-3.207} \cdot(W+2)^{-1.017}$.

The verification of the proposed model (5) was carried out by backward substitution of $D, P$, and $W$ values from Table 5 . The results of model verification using the line of agreement are shown in Fig. 1; a comparison of actual fatalities with the calculated ones can also be seen in Table 8 . The graph shows acceptable accuracy when taking into account the uncertainties in the estimation of material losses during a flood and in the evaluation of preparedness and warning factors. The agreement of results is also influenced when other contributing factors affecting the number of fatalities are neglected (see Table 4).

\section{The application of the model}

A locality was chosen for the demonstration and application of the loss of life model: the town of Krnov, which lies on the Opava River in the north of the Czech Republic. The theoretical analysis was carried out for floods corresponding to the return periods $N=2,5,10,20,50,100$, and 500 years. For these floods the exceedance probability $p$ was evaluated using the formula

$p=1-e^{-\frac{1}{N}}$.

For the studied floods, flooded areas and material losses $D$ were evaluated using the official Czech methodology (Guideline, 2008) employing damage functions and asset values for structures located in the flooded area (CSO, 2009). Then, quantifier $P$ was evaluated according to formula (1) and $W$ according to formula (2) using the method described in Sect. 3.3. Finally, the loss of life LOL was estimated for each flood scenario using formula (5). The results are shown in Table 9.

The dependence $p=G(\mathrm{LOL})$ was plotted on a logarithmic scale in a so-called $\mathrm{F}-\mathrm{N}$ diagram and compared with acceptable and tolerable risk margins (Fig. 2).

These margins were recommended for the Czech Republic within past research (Drbal et al., 2011). The relations for the acceptable risk $\mathrm{RI}_{\mathrm{P}}$ and tolerable risk $\mathrm{RI}_{\mathrm{T}}$ are expressed via the corresponding constants $C_{\mathrm{P}}$ and $C_{\mathrm{T}}$ using so-called "aversion factors", $k_{\mathrm{P}}$ and $k_{\mathrm{T}}$ :

$\mathrm{RI}_{\mathrm{P}}=G_{\mathrm{P}}(\mathrm{LOL}) \cdot \mathrm{LOL}^{k \mathrm{P}}=C_{\mathrm{P}} ;$

$\mathrm{RI}_{\mathrm{T}}=G_{\mathrm{T}}(\mathrm{LOL}) \cdot \mathrm{LOL}^{k_{\mathrm{T}}}=C_{\mathrm{T}}$,

where $G_{\mathrm{P}}(\mathrm{LOL})$ and $G_{\mathrm{T}}(\mathrm{LOL})$ are the exceedance probabilities for acceptable and tolerable risk, respectively. Based on experience from other fields and countries the constants proposed for the Czech Republic are as follows (Drbal et al., 2011):

$C_{\mathrm{P}}=10^{-3}$, for $\mathrm{LOL}=1 ; C_{\mathrm{P}}=10^{-5}$, for $\mathrm{LOL}=10 ; k_{\mathrm{P}}=2$

$C_{\mathrm{T}}=10^{-1}$, for $\mathrm{LOL}=1 ; C_{\mathrm{T}}=10^{-4}$, for $\mathrm{LOL}=100 ; k_{\mathrm{T}}=1.5$.

Figure 2 shows that floods with return periods of 5100 years do not agree with the acceptable risk requirements.

A more detailed description of the designation of acceptable and tolerable risk margins such as the ALARP concept and methodology is outside the scope of this paper. More detailed information can be found for example in HSE (2001), Jonkman et al. (2002), Trbojevic (2004), Drbal et al. (2011), and others. 
Table 8. Comparison of real casualties with those estimated using Eq. (5).

\begin{tabular}{|c|c|c|c|c|c|}
\hline \multicolumn{2}{|c|}{ Flood event } & \multirow{2}{*}{$\begin{array}{l}\text { Number of } \\
\text { casualties LOL }\end{array}$} & \multirow{2}{*}{$\begin{array}{l}\text { Estimated number of } \\
\text { casualties LOL } \\
\text { using Eq. (5) }\end{array}$} & \multirow{2}{*}{$\begin{array}{l}\text { Relative } \\
\text { difference } \\
r[\%]\end{array}$} & \multirow{2}{*}{$\begin{array}{l}\text { Absolute } \\
\text { difference }\end{array}$} \\
\hline Date & Locality & & & & \\
\hline 1997 - July & Czech Republic & 49 & 45.6 & -7 & -3.4 \\
\hline 1998 - July & Czech Republic & 10 & 11.7 & 17 & 1.7 \\
\hline 2000 - March & Czech Republic & 2 & 2.7 & 36 & 0.7 \\
\hline 2002 - August & Czech Republic & 17 & 12.1 & -29 & -4.9 \\
\hline 2006 - spring & Czech Republic & 11 & 4.0 & -63 & -7.0 \\
\hline 2009 - June & Czech Republic & 18 & 6.7 & -63 & -11.3 \\
\hline 2010 - May, June & Czech Republic & 3 & 3.2 & 6 & 0.2 \\
\hline 2010 - August & Czech Republic & 5 & 6.1 & 22 & 1.1 \\
\hline 1997 - July & Slovakia & 1 & 4.9 & 393 & 3.9 \\
\hline 1998 - July & Slovakia & 47 & 27.6 & -41 & -19.4 \\
\hline 1999 - July & Slovakia & 1 & 3.9 & 287 & 2.9 \\
\hline 2002 - August & Austria & 9 & 9.0 & 0 & 0.0 \\
\hline 2005 - August & Austria & 3 & 0.8 & -72 & -2.2 \\
\hline 2009 - July & Austria & 1 & 0.8 & -21 & -0.2 \\
\hline 2000 - October & Switzerland & 16 & 7.3 & -54 & -8.7 \\
\hline 2005 - August & Switzerland & 6 & 10.5 & 74 & 4.5 \\
\hline 2007 - August & Switzerland & 1 & 3.8 & 284 & 2.8 \\
\hline 1997 - July & Poland & 54 & 44.8 & -17 & -9.2 \\
\hline 2002 - August & Germany & 21 & 17.4 & -17 & -3.6 \\
\hline
\end{tabular}

Table 9. Loss of life estimated for the Krnov locality.

\begin{tabular}{llllll}
\hline $\begin{array}{l}\text { Return } \\
\text { period }\end{array}$ & $G(\mathrm{LOL})$ & $\begin{array}{l}D \\
\text { [mil. USD] }\end{array}$ & $P$ & $W$ & $\begin{array}{l}\text { LOL } \\
\text { estimate }\end{array}$ \\
\hline 500 & 0.0020 & 3.709 & 0.55 & 0.52 & 0.48 \\
100 & 0.0100 & 2.659 & 0.61 & 0.52 & 0.40 \\
50 & 0.0198 & 1.426 & 0.63 & 0.52 & 0.31 \\
20 & 0.0488 & 0.536 & 0.63 & 0.52 & 0.21 \\
10 & 0.0952 & 0.314 & 0.73 & 0.52 & 0.15 \\
5 & 0.1813 & 0.105 & 0.73 & 0.52 & 0.10 \\
2 & 0.3935 & 0 & 0.73 & 0.52 & 0.00 \\
\hline
\end{tabular}

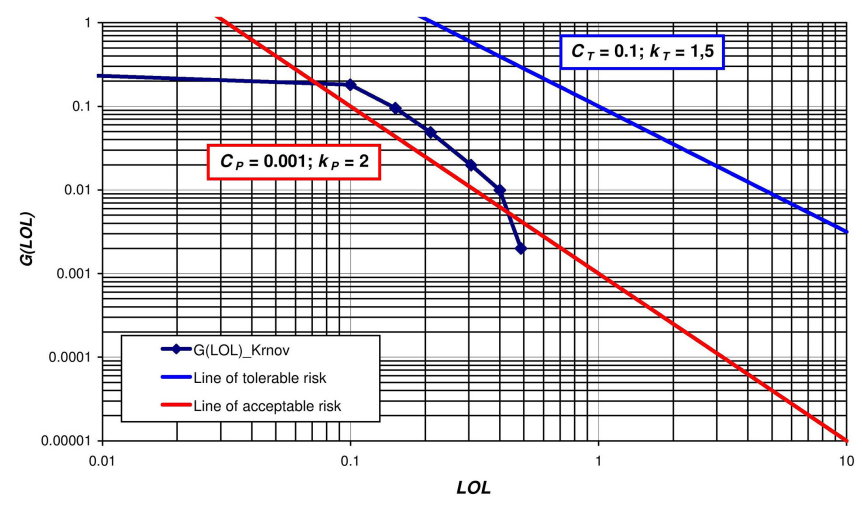

Figure 2. F-N curve for the Krnov locality.

\section{Conclusions}

In this paper a simple model for the prediction of the number of human losses during river floods is proposed. Firstly, all relevant contributing factors affecting the number of fatalities during floods were listed and ordered according to their significance. It was shown that the most important factors are related to the flood hazard, the preparedness of inhabitants and activities related to warning. These significant factors include water depth and velocity, evacuation and rescue activities, hydrological forecasting, the flood warning time and the response to it, the speed of the flood's arrival and the rate of water level rise. These factors were aggregated into three groups D, P, and W. Group D expresses material losses (in our case in USD) and includes factors related to the flood hazard as well as the number of inhabitants in the exposed area (PAR). Factors related to groups $\mathrm{P}$ and $\mathrm{W}$ were subjected to semi-quantitative scoring. The values of corresponding parameters $D, P$, and $W$ were calculated for 19 selected floods and related to real numbers of human losses during these floods (Table 5).

The parameters LOL, $D, P$, and $W$ were subjected to dependence analysis, which outlined the form of the resulting formula as a power function. The exponents in the proposed formula (4) were determined by the least square method using data from 19 selected past floods. The resulting Eq. (5) was verified by backward substitution of values $D, P$, and $W$ for individual floods when calculated LOL values were 
compared with real fatalities identified during real floods. Even though there is a relative difference between modelled and real values of more than $300 \%$ in cases when single fatalities occurred (an absolute difference of 2 or 3 fatalities), in the case of the more catastrophic floods the relative error does not exceed $50 \%$. This agreement can be regarded as acceptable when considering uncertainties in the calculations of material losses, the certain subjectivity and lack of accurate data in the scoring of preparedness and warning factors, and when neglecting the remaining, less important contributing factors. Similar differences between reported mortality figures and calculated results are shown by Jonkman et al. (2008).

The proposed model can be applied in flood protection studies when assessing the acceptability of the number of human lives lost during floods ( $\mathrm{F}-\mathrm{N}$ diagrams). The number of expected fatalities during floods is a necessary input in multicriteria risk analysis. To quantify parameter $D$ the results of hydraulic modelling of individual flood scenarios and the estimation of corresponding flood losses are necessary. For the determination of $P$ and $W$ it is crucial to have detailed information about the area and river basin, in addition to regarding individual items giving an idea of the preparedness and warning procedures in the country and area, and their reliability.

The location of data sources (Table 5) used during the construction of model (5) limit the applicability of the proposed model to inland floods in countries and areas of central Europe with similar terrain morphology, land cover, climate conditions, population density and living standards. The method is not suitable for estimating loss of life in coastal floods, hurricanes, etc.

Acknowledgements. The paper contains results from Ministry of the Environment of the Czech Republic research project No. SP/1c2/121/07 Risk maps resulting from flood danger in the Czech Republic.

Edited by: L. Ferraris

Reviewed by: S. Traverso and D. Miozzo

\section{References}

Abt, S. R., Wittler, R. J., Taylor, A., and Love, D. J.: Human stability in a high flood hazard zone, Water Resources Bulletin, J. Am. Water Resour. As., 25, 881-890, 1989.

BAFU: Hochwasser 2005 in der Schweiz, Synthesebericht zur Ereignisanalyse, Bundesamt für Umwelt, Switzerland, 24 pp., 2008 (in German).

BAFU: Ereignisanalyse Hochwasser August 2007. Analyse der Meteo- und Abflussvorhersagen; vertiefte Analyse der Hochwasserregulierung der Jurarandgewässer, Bundesamt für Umwelt, 211 pp., 2009 (in German).

BLFUW: Hochwasser 2005 - Ereignisdokumentation. Teilbericht des Hydrographischen Dienstes, Bundesministerium für Land- und Forstwirtschaft, Umwelt und Wasserwirtschaft, 30 pp., 2006 (in German).

Brown, C. A. and Graham, W. J.: Assessing the threat to life from dam failure, Paper No. 88044 of the Water Resources Bulletin, J. Am. Water Resour. As., 24, 1303-1309, 1988.

CHMI: The spring flood of 2006 in the Czech Republic, Final Report, Ministry of the Environment of the Czech Republic, 158 pp., 2006 (in Czech).

CHMI: Assessment of the floods of June and July 2009 on the territory of the Czech Republic, Final Report, Ministry of the Environment of the Czech Republic, Prague, 131 pp., 2009 (in Czech).

CHMI: Assessment of the floods of May and June 2010, Report, Ministry of the Environment of the Czech Republic, Prague, 167 pp., 2010a (in Czech).

CHMI: Assessment of the August 2010 flood, Report, Ministry of the Environment of the Czech Republic, Prague, 131 pp., 2010b (in Czech).

CNB: available at: http://www.kurzy.cz, last access: 10 March 2014.

COSMC: Fundamental basis of geographical data (ZABAGED), Czech office for surveying, mapping and cadastre, Prague, available at: http://www.cuzk.cz, last access: 12 June 2014, 2009.

CSO: Census District and Building Register. Czech statistical office, Prague, available at: http://www.czso.cz/csu/rso.nsf/i/ registr_scitacich_obvodu, last access: 12 June 2014, 2009.

DeKay, M. L. and McClelland, G. H.: Predicting loss of life in cases of dam failure and flash flood, Risk Anal., 13, 193-205, 1993.

Directive 2007/60/EC of the European Parliament and of the Council of 23 October 2007 on the assessment and management of flood risks, 2007.

DKKV: Hochwasservorsorge in Deutschland, Lernen aus der Katastrophe 2002 im Elbegebiet, Deutsches Komitee für Katastrophenvorsorge e. V., Bonn, 152 pp., 2003 (in German).

Drab, A. and Riha, J.: An approach to the implementation of European Directive 2007/60/EC on flood risk management in the Czech Republic. Nat. Hazards Earth Syst. Sci., 10, 1977-1987, 2010 , http://www.nat-hazards-earth-syst-sci.net/10/1977/2010/.

Drbal, K., Rektorik, J., Riha, J., Satrapa, L., Slavikova, L., and Stepankova, P.: Risk maps resulting from flood danger in the Czech Republic, Final report, Brno, available at: http://www.vuv. cz/index.php?id=290, 1-84, 2011 (in Czech)

ERA: Final report on the March 2000 flood in the Elbe River basin, Elbe River Agency, Hradec Králové, 25 pp., 2000 (in Czech).

ERA: The catastrophic 1998 flood in the Orlicke hory region, 10 years after the flood, Elbe River Agency, Hradec Králové, 2009 (in Czech).

Friedman, D. G.: Computer simulation in natural hazard assessment, Institute of Behavioral Science, University of Colorado, Boulder, Colorado, 194 pp., 1975.

Godina, R. and Müller, G.: Das Hochwasser in Österreich vom 22. bis 30. Juni 2009, Beschreibung der hydrologischen Situation Abteilung VII/3 - Wasserhaushalt (HZB), Bundesministerium für Land- und Forstwirtschaft, Umwelt und Wasserwirtschaft, Vienna, 21 pp., 2009 (in German).

Gouldby, B. and Samuels, P.: Language of Risk, Report T32-04-01, FLOODsite Consortium, available at: http://www.floodsite.net/, 2005. 
Graham, W. J.: Floods caused by dam failure, Dam Safety Office report DSO-99-6, 1999.

Guideline for the assessment of flood risk and losses in floodplains, The Ministry of Environment of the Czech Republic, Water Research Institute, available at: http://www.vuv.cz/index.php?id= 290, last access: 12 June 2014, December 2008 (in Czech).

Habersack, H. and Moser, A. (Eds.): Plattform Hochwasser Ereignisdokumentation. Hochwasser August 2002, ZENAR, in collaboration with Bundesministerium für Land und Forstwirtschaft, Umwelt und Wasserwirtschaft, Vienna, 232 pp., 2003 (in German).

HSE - Health and Safety Executive: Reducing risks, protecting people, HSE's decision-making process, London, UK, 88 pp., 2001.

Hübl, J., Miklau, F. R., and Schattauer, G.: Ereignisdokumentation 2009. Bericht über die Wildbachereignisse von April bis Oktober 2009 in Österreich, Bundesministerium für Land- und Forstwirtschaft, Umwelt und Wasserwirtschaft, Vienna, 98 pp., 2009 (in German).

Jonkman, S. N.: Loss of life estimation in flood risk assessment, Theory and applications, Dissertation, Delft University of Technology, Delft, the Netherlands., 360 pp., 2007.

Jonkman, S. N. and Kelman, I.: An analysis of the causes and circumstances of flood disaster deaths, Overseas Dev. Institute, Oxford, UK, p. 75-97, 2005.

Jonkman, S. N. and Rowsell, E. P.: Human Instability in Flood Flows, J. Am. Water Resour. As., 44, 1-10, 2008.

Jonkman, S. N., Gelder, P. H. A. J. M., and Vrijling, J. K.: Loss of life models for sea and river floods, Flood Defense 2002, Vol. I, Science Press, New York, 2002.

Jonkman, S. N., Vrijling, J. K., and Vrouwenvelder, A. C. W. M.: Methods for the estimation of loss of life due to floods: a literature review and a proposal for a new method, Nat. Hazards, 46, 353-389, 2008.

Jonkman, S. N., Maaskant, B., Boyd, E., and Levitan, M. L.: Loss of Life Caused by the Flooding of New Orleans After Hurricane Katrina: Analysis of the Relationship Between Flood Characteristics and Mortality, Risk Anal., 29, 676-698, 2009.

Kelman, I.: CURBE fact sheet 3: U.K. Deaths from the 1953 Storm Surge, Version 3, July 2003.

Lee, R., Hu, P. S., Neal, D. M., Ogles, M. R., Sorensen, J. H., and Trumble, D. A.: Predicting loss of life from floods, Oak Ridge National Laboratory Draft Report, prepared for the Institute for Water Resources, U.S. Army Corps of Engineers, 131 pp., 1986.

Lind, N. and Hartford, D.: Probability of Human Instability in a Flooding: A Hydrodynamic Model, in: Proceedings, Int. Congress on Applications of Statistics and Probability, Balkema, Rotterdam, 1151-1156, 2000.

Lind, N., Hartford, D., and Assaf, H.: Hydrodynamic models of human stability in a flood, J. Am. Water Resour. As., 40, 89-96, doi:10.1111/j.1752-1688.2004.tb01012.x, 2004.

MACR: Program documentation No. 129120 "Maintenance of flood prevention I", Ministry of Agriculture of the Czech Republic, Prague, 2006.

MARD: The flood protection programme in the SR until the year 2010, Ministry of Agriculture and Rural Development of the Slovak Republic, Bratislava, 1999 (in Slovak).
McClelland, D. M. and Bowles, D. S.: Estimating life loss for dam safety risk assessment - a review and new approach, IWR Report 02-R-3, USACE, 403 pp., 2002.

Petrascheck, A. and Hegg, Ch. (Eds.): Hochwasser 2000. Ereignisanalyse/Fallbeispiele. Berichte des BWG, Serie Wasser, Bundesamt für Wasser und Geologie, Bern, 250 pp., 2002 (in German).

Priest, S., Wilson, T., Tapsell, S., Penning-Rowsell, E., Viavattene, Ch., and Fernandez-Bilbao, A.: Building a Model to Estimate Risk to Life for European Flood Events - Final Report, Report number T10-07-10, Floodsite, HR Wallingford, UK, 174 pp., 2007.

Ramsbottom, D., Floyd, P., and Penning-Rowsell, E.: Flood Risks to People, Phase 1, R\&D Technical Report FD 2317, Defra Flood Management Division, London, UK, 109 pp., 2003.

Ramsbottom, D., Wade, S., Bain, V., Hassan, M., Penning-Rowsell, E., Wilson, T., Fernandez, A., House, M., and Floyd, P.: Flood Risks to People, Phase 2, R\&D FD2321/IR2 Food and Rural Affairs/Environmental Agency, 2004.

RESCDAM: The Use of Physical Models in Dam-break Flood Analysis, Final Report, Helsinki University of Technology, Finland, 57 pp., 2000.

Saaty, T. L.: Relative measurement and its generalization in decision making: why pairwise comparisons are central in mathematics for the measurement of intangible factors - the analytic hierarchy/network process, RACSAM Rev. Rev. R. Acad. A, 102, 251-318, 2008.

Salaj, M.: Flood Risks Analysis for Humans, Ph.D. Thesis, Czech Technical University in Prague, 85 pp., 2009.

Surendran, S. Ramsbottom, D., Wade, S., Bain, V., Floyd, P., Penning-Rowsell, E., Wilson, T., Fernandez, A., and House, M.: Flood Risks to People, Phase 2, FD 2321/TR1 The Flood Risk to People Methodology, DEFRA -Department for Environment, Food and Rural Affairs, Flood 20 Management Division, London, 92 pp., 2006.

The World Bank: available at: http://data.worldbank.org/indicator, last access: 10 March 2014.

Trbojevic, V. M.: Risk criteria in EU, Paper presented at SAFERELNET workshop, Paris, France, 2004.

Vrouwenvelder, A. C. W. M. and Steenhuis, C. M.: Secondary flood defences in the Hoeksche Waard, calculation of the number of fatalities for various flood scenarios, Report TNO 97-CON-R0332, 1997.

Waarts, P. H.: Method for determining loss of life caused by inundation, Report TNO B-91-1099, Delft, the Netherlands, 1992.

WRI: Evaluation of the flood in July 1997, CD ROM 1-8, 1997 (in Czech).

WRI: Assessment of the catastrophic August 2002 flood in the Czech Republic, Final Report, Ministry of the Environment of the Czech Republic, 160 pp., 2002 (in Czech).

Zhai, G., Fukuzono, T., and Ikeda, S.: An empirical model of fatalities and injuries due to floods in Japan, J. Am. Water Resour. As., 42, 863-875, 2006. 